\title{
Comments on 'Green economics: setting the scene. Aims, context, and philosophical underpinnings of the distinctive new solutions offered by green economics'
}

\author{
Jack Reardon \\ Social Science Department \\ University of Wisconsin-Stout \\ Menomonie, Wisconsin 54701, USA \\ E-mail: reardonJ@uwstout.edu
}

\begin{abstract}
This article critiques the paper by Kennet and Heinemann, 'Comments on green economics: setting the scene. Aims, context and philosophical underpinnings of the distinctive new solutions offered by green economics'. Their task is difficult since green economics holistically embraces ideas from a wide spectrum of multi-disciplinary fields. The purpose of this paper is to pose clarification questions and offer suggestions for future research such as whether we should amend or supplant neoclassical economics; the role of the corporation, the specific meaning of the precautionary principle and sustainability; the role of education in promoting green economics and how to transit between our current economic system based on over-stimulated consumption and unrestricted economic growth to an economy based on the principles of green economics. Kennet and Heinemann (2006) largely succeed in their task of setting the scene for green economics. These comments are offered in the friendly manner of stimulating further research and discussion.
\end{abstract}

Keywords: green economics; neoclassical economics; sustainability; precautionary principle; economic education.

Reference to this paper should be made as follows: Reardon, J. (2007) Comments on 'Green economics: setting the scene. Aims, context, and philosophical underpinnings of the distinctive new solutions offered by green economics', Int. J. Green Economics, Vol. 1, Nos. 3/4, pp.532-538.

Biographical notes: Jack Reardon is Professor of Economics at the University of Wisconsin-Stout (USA). His research interests include energy and the environment, economic education and labour economics. He recently served on the editorial board of the Journal of Economic Issues and is a member of Pakistan's Panel of Foreign Experts where he evaluates Pakistani professors for promotion. He frequently contributes to local newspapers and is a regular book reviewer for the Milwaukee Journal Sentinel. He is currently finishing a book, A Handbook for Pluralist Economic Education.

\section{Introduction}

Kennet and Heinemann (2006, pp.68-102) have largely succeed in 'setting the scene' for green economics.

Copyright (C) 2007 Inderscience Enterprises Ltd. 
In addition, the authors deserve a prize for the longest title in the journal's inaugural issue. The prolix title, however, underscores the formidable task of introducing green economics, which holistically embraces ideas from a wide spectrum of multi-disciplinary fields. The central tenets of green economics include sustainability, localised production and distribution, respect for ecological constraints and a more equitable distribution of resources.

The purpose of this critique is to tie together some of the article's loose ends, pose clarification questions and offer suggestions for future research. My comments are divided into three sections: epistemological, clarification and methodological. These comments are not meant to be definitive but are proffered in the friendly manner of stimulating discussion.

\section{Epistemological}

\subsection{How new is green economics?}

The authors state that green economics is new - it is compared to neoclassical economics which was formed during an era when "economists thought, wrote, and prescribed as if nature did not" (McNeil, 2000, p.335). But is it really new? While some societies have self-destructed due to ecological ignorance and arrogance (Pointing, 1991; Diamond, 2005) others have thrived living within ecological constraints. Records indicate, for example, that the cultures of "many Native American peoples ... evolved over thousands of years largely in symbiosis of the earth that sustained it. Often these customs were incorporated into religious rituals that held the earth to be the sustainer of all things and linked the welfare of the earth to the survival of the people who lived upon it" (Grinde and Johansen, 1995, p.52).

Although intellectual antecedents cited by Kennet and Heinemann are instructive, a suggested research topic for the historians among us is to construct a pre-capitalist lineage to societies that practised sustainability and localised production - not as homage to a simpler time, but to recognise our intellectual debts and ascertain what lessons can be learned.

\subsection{The relationship between green economics and neoclassical economics}

Kennet and Heinemann (2006) are ambiguous on this important point. They write that green economics "critiques neoclassical economics ... proposing reform where needed at times" (p.69); and that it brings "new perspectives to conventional economics" (p.71). Yet they also write, "our aim is to create a new discipline" (p.70) and that green economics "provide[s] a sorely needed fresh and radical approach to complete reform of economics ... . and a truly radical departure" (p.96).

How much to retain and how much to discard is a legitimate area of debate. Do we want to amend or supplant? Are there areas of conventional economics worth keeping? If so, why?

I believe that even if amended, neoclassical economics is ill-equipped to recognise, understand and solve our burgeoning ecological problems. If we are to implement a new system "we must combat what we have been taught with our own social vision, not just fragments ... we must think anew ... we must unlearn economics" (Dowd, 2004, pp.226-227). 


\subsection{Sister disciplines and their contributions to green economics}

The authors acknowledge the influence of sister disciplines such as welfare economics, Buddhist economics, environmental and post-autistic economics (2006, pp.84-89). Although any journal review cannot be encyclopaedic, a notable omission is institutional economics which has a rich and holistic concern with ecology and the environment (Swaney, 1987). A modus operandi of institutional economics is the instrumental value principle which posits "the continuity of human life and the non-invidious re-creation of community through the instrumental use of knowledge" (Tool, 2001, p.293). In English this means institutionalists respect life in all its forms, acknowledge the importance of the individual, advocate the precautionary principle, implement economic policies to eliminate poverty and under-development that are consistent with species survival. In addition, institutionalists are centrally concerned with the existence and use of corporate power, as is green economics, which attempts to "reveal, disentangle, and untangle the power relationships and vested interests in the new global marketplace" (Kennet and Heineman, 2006, p.71).

A definitive source for understanding institutionalism is The Discretionary Economy (Tool, 2001). Institutionalists publish their research in The Journal of Economic Issues, and the newly launched Journal of Institutional Economics. An excellent source for understanding the role of institutions and the differences among institutionalists is Institutions and the Environment (Vatn, 2005).

A suggested research topic is to document the similarities and differences between institutionalists and greens. Perhaps we can engage in collaborative research on topics such as corporate power, sustainability and democratic use of resources.

\section{Concepts in need of clarification}

\subsection{The corporation}

Kennet and Heinemann (2006) indict the corporation "as agents of hegemony, being undemocratic, unelected, uniform, lacking in transparency and being the fundamental cause of the problem" (p.87). But if so, should they be dismantled, down-sized or regulated?

Herein exists a catch-22: Large corporations by achieving economies of scale can produce cheaper goods and services thus cementing consumer loyalty. Wal-Mart, for example recently pledged to use "its purchasing and distribution process to reduce prices on sales of its generic drugs by an average on 20 percent" (McWilliams and Martinez, 2006, p.B1). At the same time, large corporations can use their market power to either prevent change or usurp momentum for their own benefit. Unlike today's corporations which, for the most part have been given a carte blanch (abetted by the ideology of neoclassical economics) to operate anywhere to make a profit, antebellum US corporations, "were kept under watchful citizen and government control ... the intent was to keep that power as close as possible to citizen control" (Korten, 1995, pp.55-57).

How do we transit from the current global marketplace dominated by large multinational corporations to green economics characterised by localised production and distribution? What specific policies can be implemented to attenuate corporate power and restore economic democracy? 


\title{
3.2 The precautionary principle
}

As the authors note, the precautionary principle is central to green economics (2006, p.70). In its simplest form, the precautionary principle states:

\begin{abstract}
"When an activity raises harmful threats to either human health or the environment, precautionary measures should be taken even in the absence of fully-established scientific proof. The proponent of the activity, rather than the public should bear the burden of proof. The process of applying the precautionary principle must be open, informed, democratic and must include potentially affected parties. It must involve the examination of the full range of alternatives, including no action."
\end{abstract}

While this is a powerful argument against change in the face of environmental uncertainty, it also could be highjacked by powerful vested interests to prevent change in the status quo while masquerading in the public interest. What safeguards are available to prevent the highjacking of this important principle?

\subsection{Sustainability}

The authors critique sustainable development as an oxymoron (2006, p.87) Does this reflect the ostensible sustainable practises of corporations, yielding a veneer of caring reform and sustainability, yet masking the continued pursuit of profit? Or do the authors reject the quintessence of sustainability? How is sustainability defined and how is it attained?

\subsection{Green political economy}

Finally, I would to make a plug for changing the name 'green economics' to 'green political economy'. I have no objections to the word 'green,' but because of the hegemony of neoclassical economics, economics has become disparagingly synonymous with neoclassical, thereby rendering, at least in my mind, the juxtaposition of green and economics an oxymoron.

The term political economy, however, is holistic, pluralistic and open-minded. Bowles et al. (2005) explain, that before the 20th century:
"political economy referred to all of economics ... encompassing most of what is now divided up among the social sciences: anthropology, sociology, psychology, and political economics as well as economics. But around 1900 the term political economy was replaced by economics and [its] boundaries were narrowed: the study of markets became its primary focus. Inquiries into politics, psychology, history and other aspects of society were left to the other social sciences." (p.51)

Bowles et al. (2005) offer a tantalising rationale for resuscitating the term political economy:

"One cannot understand contemporary societies very well unless politics, economics, psychology, and the other social science disciplines are all brought together to study the complexities of modern life. Another way of describing the political economy approach, then, is to say that it is interdisciplinary." (p.51) 
Likewise green economics, "examines reality by means of multidisciplinary, complex, holistic, and very long-term methods as well as [incorporating] political and social aspects" (2006, p.70). Therefore I would like to suggest that perhaps the journal, could be renamed, The International Journal of Green Economics and Political Economy? What do other readers think?

\section{Methodological comments}

\subsection{Transition}

The current economic system of over-stimulated consumption and unrestricted economic growth is unsustainable: it impoverishes people, exacerbates inequality and destroys the environment. Green Economics, on the other hand, promotes "fairness, equity, participation and democracy with social and environmental justice at its core" (Kennet and Heinemann, 2006, p.70).

But will this new system be imposed, say by an ecological catastrophe, or will it be selected? If selected, how? And who will be the decision-makers? The answers to such questions will affect not only the transition process but the new economic system itself.

Although transitions were briefly discussed elsewhere in the inaugural issue (Wall, 2006) Kennet and Heinemann should have at least mentioned how the aims, context and philosophical underpinnings of green economics will affect the determination and selection of specific transitions.

Wall (2006, p.212) argues that "a more detailed examination of questions of transition is vital if green economics [is] to mature as a discipline and provide a path to the future". He discusses two transitions in a non-specific manner: agriculture and transportation. The common denominator is cheap fossil fuels which has abetted the formation of large-scale agriculture, highly mobile corporations and has fostered globalisation to the detriment of the environment (Kunstler, 2005, pp.186-188). Take away cheap fuel and localised production will become reality, but in a brutish and cataclysmic manner, with "hunger instead of plenty, cold where there was once warmth, effort where there was once leisure, sickness where there was health and violence where there was peace" (Kunstler, 2005, p.303).

Green economics should foster a democratic, humane and peaceful transition. Rather than wait until fossil fuels become scarce and global warming becomes catastrophic we should begin implementing alternative energy regimes now. Renewable energy such as wind and solar is consistent with the green economics since it relies on local energy sources, empowers local communities and obviates the need for large, centrally integrated top-down corporations (Rifkin, 2002, p.206). A hydrogen economy, despite its current problems, is also consistent with green economics, if the hydrogen can be produced with renewable energy. Although hydrogen is plentiful it does not exist in pure form and energy must be expended to extract and produce hydrogen. Currently natural gas is the preponderant fuel to produce hydrogen, but if renewable energy is used this will potentially "connect communities all over the world [and] is the only way to lift billions of people out of poverty ... such distributed-generation energy webs are the core strategy for building sustainable, self-sufficient communities" (Rifkin, 2002, pp.237-240) 
A formidable obstacle in any transition is large fossil fuel corporations which can use their market power to parry a transition away from fossil fuels. Currently, fossil fuel corporations are using their profits to acquire stakes in renewable companies, buying renewable companies, and forming alliances, thus usurping the decision when and if to implement renewable technology (Reardon, 2006).

Research is needed on energy regimes consistent with green economics and how best to achieve the transition with a concomitant documentation of existing obstacles along with suggestions to surmount these obstacles.

\subsection{Education and dissemination of our message}

Education is necessary to understand the historical evolution of capitalism and to understand the differences between societies based on the principles of green economics and societies addicted to economic growth. Green education should be established at all levels along with ambassadors to the public disseminating a systematic yet optimistic message. If portrayed optimistically, it is my sense that the public, sensing something is wrong with our current system (Dowd, 2004, p.xii) will be somewhat sympathetic.

\section{Conclusion}

Kennet and Heinemann succeed in the formidable task of 'setting the scene' for green economics. If green economics is to supplant mainstream economics than we must "renew our normative critique of both the principles and the resulting consequences of conventional economics" (Wall, 2006, p.212). Kennet and Heinemann (2006) offer green economics as "the correct and holistic and objective framework to develop [a] fundamental alternative and to help economic thinking out of its self-imposed gridlock" (p.84). Hopefully, my comments have clarified some of the criticisms of mainstream economics and some of the issues underpinning this holistic and objective framework, while raising points for discussion and future research.

\section{References}

Bowles, S., Edwards, R. and Roosevelt, F. (2005) Understanding Capitalism: Competition, Command and Change, Oxford: Oxford University Press.

Diamond, J. (2005) Collapse - How Societies Choose to Fail or Succeed, New York: Penguin.

Dowd, D. (2004) Capitalism and its Economics - A Critical History, London: Pluto Press.

Grinde, D.A. and Johansen, B.E. (1995) Ecocide of Native America, Santa Fe, New Mexico, Clear Light.

Kennet, M. and Heinemann, V. (2006) 'Green economics: setting the scene. Aims, context and philosophical underpinning of the distinctive new solutions offered by green economics', International Journal of Green Economics, Vol. 1, Nos. 1-2, pp.68-102.

Korten, D.C. (1995) When Corporations Rule the World, West Hartford, CT: Kumarian Press.

Kunstler, J.H. (2005) The Long Emergency, New York: Atlantic Monthly Press.

McNeil, J.R. (2000) Something New Under the Sun - An Environmental History of the Twentieth Century World, New York: W.W. Norton. 
McWilliams, G. and Martinez, B. (2006) 'Wal-Mart cuts prices for many generic drugs to \$4',

The Wall Street Journal, 22 September, pp.B1, B3.

Ponting, C. (1991) A Green History of the World, New York: Penguin

Reardon, J. (2006) The Changing Structure of the Global Energy Industry, unpublished manuscript. Rifkin, J. (2002) The Hydrogen Economy, New York: Putnam.

Swaney, J. (1987) 'Elements of a neoinstituional environmental economics', Journal of Economic Issues, Vol. 21, No. 4, pp.1739-1779.

Tool, M. (2001) The Discretionary Economy - A Normative Theory of Political Economy, New Brunswick, NJ: Transaction Publishers.

Vatn, A. (2005) Institutions and the Environment, Cheltenham, UK: Edward Elgar.

Wall, D. (2006) 'Green economics: an introduction and research agenda', International Journal of Green Economics, Vol. 1, Nos. 1-2, pp.201-214. 